\title{
Membangun Jiwa Entrepreunership Santri dan Santriwati Pondok Pesantren Al Mujahidin Balikpapan
}

\author{
Gozali \\ Politeknik Negeri Balikpapan \\ gozali@poltekba.ac.id \\ Bambang Jati Kusuma \\ Politeknik Negeri Balikpapan \\ bambang.jati@poltekba.ac.id \\ Mahfud \\ Politeknik Negeri Balikpapan \\ mahfud@poltekba.ac.id \\ Ali Arifin Soeparlan \\ Politeknik Negeri Balikpapan \\ ali.arifin@poltekba.ac.id \\ Masrul Huda \\ Politeknik Negeri Balikpapan \\ masrul.huda@poltekba.ac.id
}

\begin{abstract}
Abstrak
Kewirausahaan (entrepreneurship) ialah kemampuan kreatif dan inovatif yang dijadikan dasar, kiat, dan sumber daya untuk mencari peluang menuju sukses. Kesejahteraan atau nilai tambah dari masyarakat sebagai tujuan dari kewirausahaan itu, dilakukan melalui pengungkapan gagasan baru, penggalian sumber daya, dan merealisasikan gagasan itu menjadi suatu kenyataan yang menguntungkan.

Pelatihan ini dilaksanakan dengan memberdayakan masyarakat khususnya santri dan santriwati Pondok Pesantren Al Mujahidin Balikpapan yang beralamat di Jl. Soekarno Hatta Km. 10 Balikpapan Utara. Pelatihan dilaksanakan pada hari Kamis 13 Desember 2018 pukul 08.00 sampai selesai. Metode pelatihan yang digunakan melalui seminar young entrepreneurship, praktik langsung membuat inovasi produk kuliner (roti dan kue), dan praktik pengemasan dan pemasaran. Peserta dibagi menjadi tiga kelompok. Setiap kelompok membuat produk roti dan kue yang berbeda. Kelompok pertama praktik membuat roti manis, kelompok kedua praktik membuat muffin, kelompok ketiga membuat swiss roll.
\end{abstract}

Kata Kunci: roti, kue, kuliner, pelatihan, wirausaha 


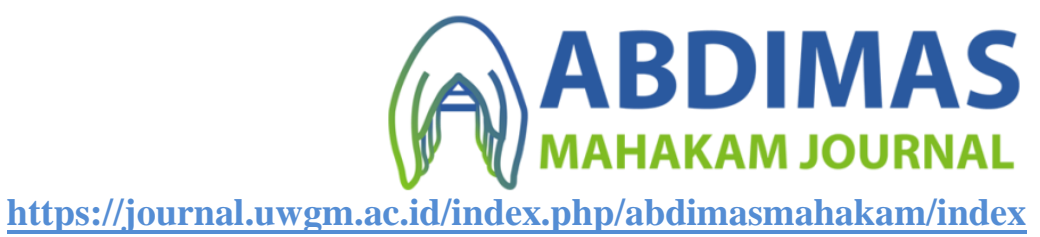

E-ISSN: 2549-5755

Januari 2019, Vol. 3 No. 1

\section{Pendahuluan}

Indonesia saat ini membutuhkan para wirausaha muda untuk dapat mendukung pertumbuhan ekonomi negara. Jumlah wirausaha di Indonesia baru mencapai 0,24 persen dari jumlah penduduk Indonesia yang mencapai 240 juta, lainnya lebih memilih jadi karyawan atau pegawai negeri sipil alias PNS. Jumlah itu lebih rendah dibandingkan dengan wirausaha di beberapa negara luar yang tingkat pertumbuhan ekonominya tinggi, seperti Amerika Serikat yang mencapai 11\%, Singapura 7\%, dan Malaysia $5 \%$, (Anas, F. 2012).

Dengan melihat perbandingan jumlah wirausaha di negara maju tersebut, wajar jika pertumbuhan perekonomian di Indonesia masih lambat, meskipun saat ini Indonesia adalahnegara dengan tingkat pertumbuhan stabil. Oleh karena itu, mau tidak mau kebijakan pemerintah harus mengarah pada mengembangkan sektor kewirausahaan dan meningkatkan jumlah wirausahawan agar dapat berperan dalam mendukung ekonomi negara. Wirausaha adalah orang yang paling diandalkan untuk mengatasi berbagai persolan ekonomi bangsa ini, (Kasali, R. 2010).

Namun harus diingat, pertumbuhan jumlah wirausahawan harus didukung oleh lembaga pendidikan, termasuk Pondok pesantren. Pendidikan penting untuk memberi modal dasar bagi para wirausahawan. Melalui jalur pendidikan dapat mengubah pola pikir seseorang untuk menjadikan wirausahawan yang bekerja dengan menggunakan ide dan kreativitas.

Pondok pesantren Al Mujahidin sebagai salah satu lembaga pendidikan Islam yang ada di Kota Balikpapan memiliki tujuan dalam menyelenggarakan pendidikan, salah satunya yaitu menghasilkan generasi Muslim dengan keterampilan yang dapat diandalkan untuk mendukung kemandirian pribadi dan kemandirian sosial.

Peran Pondok pesantren, dalam hal ini dapat memotivasi para santrinya menjadi young entrepreneurs yang merupakan bagian dari salah satu faktor pendorong pertumbuhan kewirausahaan. Siklus yang kemudian terjadi adalah dengan meningkatnya wirausahawan dari kalangan santri akan mengurangi pengangguran, serta menambah jumlah lapangan pekerjaan.

Dari hasil observasi di Pondok pesantren Al Mujahidin, metode yang digunakan untuk memotivasi para santrinya menjadi young entrepreneurs masih belum efektif. Hal itu terlihat dari struktur kurikulum sebatas mata pelajaran kewirausahaan dan sarana prasarana sebagai media untuk berwirausaha belum memadai.

Berdasarkan permasalahan tersebut, perlu diadakan pelatihan entrepreneurship untuk membangun jiwa entrepreneurship santri dan santriwati Pondok pesantren Al Mujahidin.

Tujuan pelatihan membangun jiwa entrepreunership santri dan santriwati Pondok Pesantren Mujahidin Balikpapan adalah sebagai berikut:

1. Menumbuhkan jiwa wirausaha santri dan santriwati melalui metode pelatihan bussines plan

2. Memperkenalkan usaha kuliner melalui metode pelatihan inovasi produk kuliner dan pelatihan pengemasan dan pemasaran. 


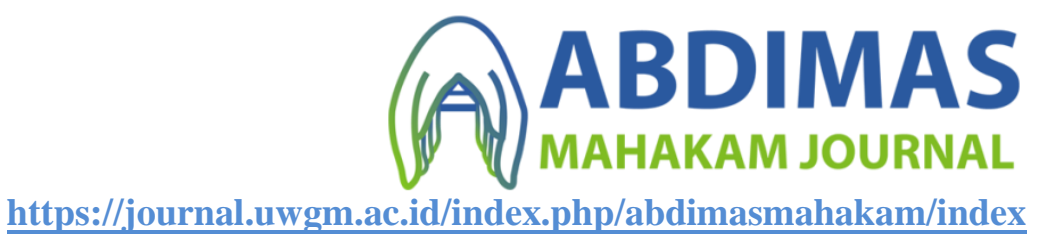

E-ISSN: 2549-5755

Januari 2019, Vol. 3 No. 1

\section{Metode}

Metode pelaksanaan Program Pengabdian kepada Mayarakat "Membangun Jiwa Entrepreunership Santri dan Santriwati Pondok Pesantren Mujahidin Balikpapan" melalui beberapa tahapan sebagai berikut:

1. Tahap pertama

Survey lokasi, pada tahap ini dilakukan pendataan jumlah santri dan santriwati Pondok pesantren Al Mujahidin.

\section{Tahap kedua}

Sosialisasi, pada tahap ini memberikan informasi yang jelas kepada santri dan santriwati Pondok pesantren Al Mujahidin.

\section{Tahap ketiga}

Pengadaan alat dan barang, pada tahap ini melakukan pengadaan barang yang tepat dan sesuai dengan kebutuhan. Dengan mencari harga yang tepat dan cocok dan sesuai serta transparant dalam mendukung kegiatan pengabdian masyarakat ini.

\section{Tahap keempat}

Pelatihan, pada tahap ini merupakan kegiatan inti dari program pengabdian kepada masyarakat yang meliputi: (1) Seminar Young Entrepreneurship dilakukan selama 1 (satu) hari di laksanakan di Ruang Restoran Jurusan Perhotelan Poliekik Negeri Balikpapan, (2) Praktik inovasi produk makanan dan minuman dilakukan selama 1 (satu) hari dilaksanakan di laboratorium kitchen Program Studi Tata Boga Politeknik Negeri Balikpapan dan dilanjutkan Pelatihan pengemasan dan pemasaran.

\section{Tahap kelima}

Pada tahap ini diberikan pendampingan secara berkelanjutan dan sistematis, untuk memastikan kualitas produk yang dihasilkan dan layak dipasarkan. Kegiatan pendampingan ini akan dilaksanakan secara berkelanjutan pasca pelatihan.

\section{Hasil dan Pembahasan}

Dari semua rangkaian kegiatan yang dilakukan, peserta pelatihan sangat antusias penuh semangat dalam mengikuti kegiatan tersebut. Antusias peserta ini dapat dilihat pada saat seminar young entrepreneurship berlangsung dan pada saat praktik membuat pruduk roti dan kue, pada kegiatan tersebut peserta banyak bertanya mulai bagaimana cara memulai usaha, dan usaha apa yang tepat untuk era sekarang dan bagaimana trik menarik konsumen serta menjaga mutu produk, bagaimana cara membuat roti yang enak dan diminati konsumen, bagaimana cara supaya roti dan kue awet tanpa bahan kimia. Peserta juga sangat termotivasi hal ini terlihat pada saat peserta prakik secara langsung membuat produk kue dan roti. Seminar young entrepreneurship dapat dilihat pada gambar 1. 


\section{(A) ABDIMAS}

https://journal.uwgm.ac.id//index.php/abdlimasmahakam/index

E-ISSN: 2549-5755

Januari 2019, Vol. 3 No. 1

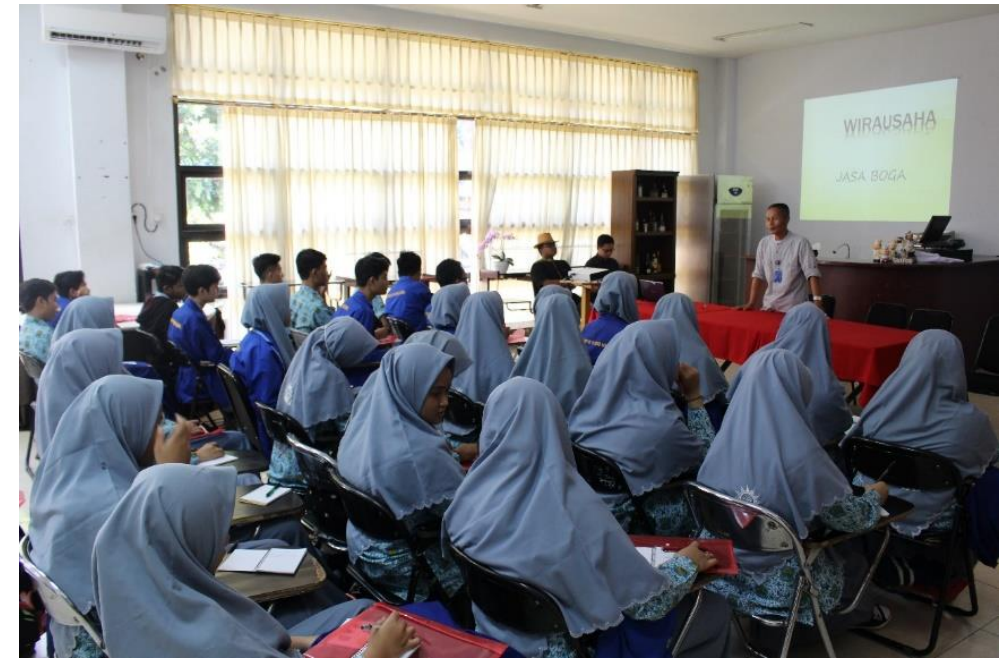

Gambar1 Seminar Young Entrepreneurship

Pada hari pertama peserta diberikan motivasi wirausaha melalui seminar young entrepreneurship. Peserta diajarkan cara untuk memulai usaha kuliner, cara mendapatkan modal, cara menentukan produk dan pasar, cara promosi dan memasarkan produk dan meningkatkan penjualan serta cara meningkatkan pendapatan. Peserta juga diajarkan cara mengembangkan usaha dan pengelolaan keuangan.

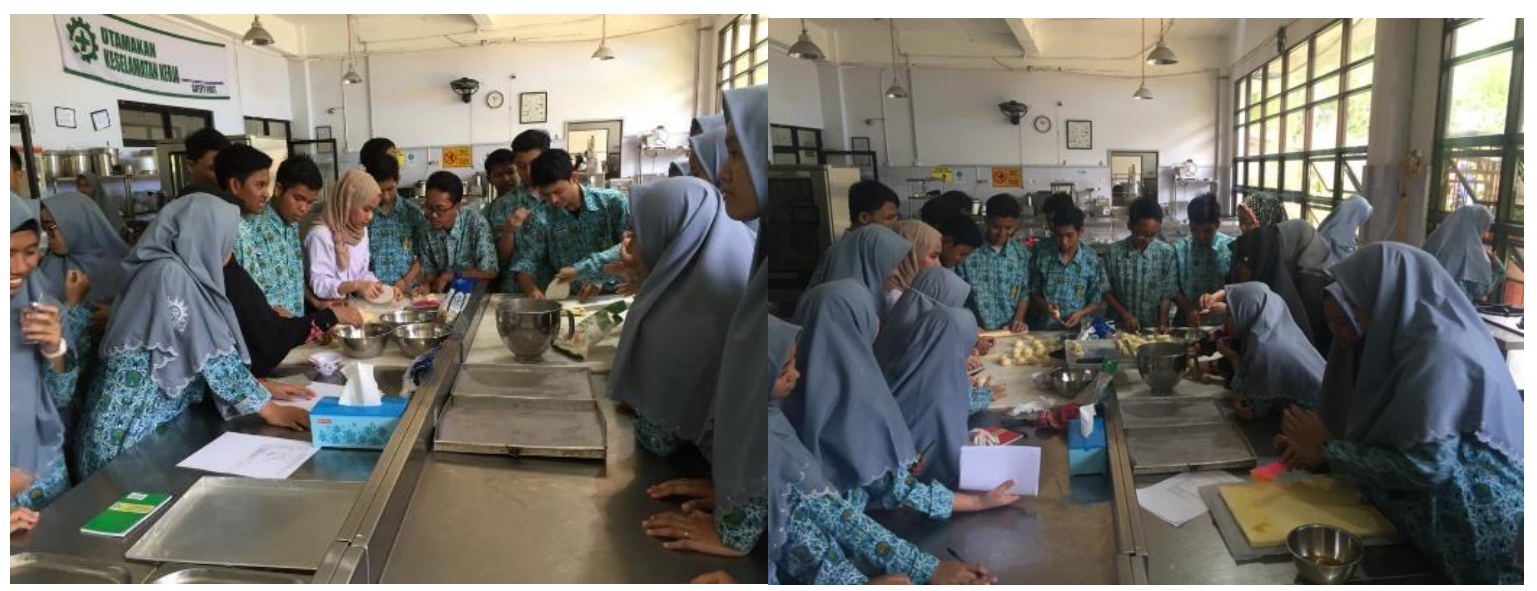

Gambar. 2 Pelatihan inovasi produk kuliner

Pada hari kedua peserta dibagi menjadi 3 kelompok masing-masing beranggota 10 orang dan diberikan pelatihan praktik secara langsung membuat produk kuliner (aneka macam roti manis). Peserta membuat roti manis mulai dari persiapan bahan, peralatan, pencampuran adonan, mengembangkan adonan, membentuk adonan, memanggang. Masing-masing kelompok membuat roti/kue yang berbeda, kelompok 1 membuat roti manis, kelompok 2 membuat muffin, kelompok 3 membuat swiss roll. 


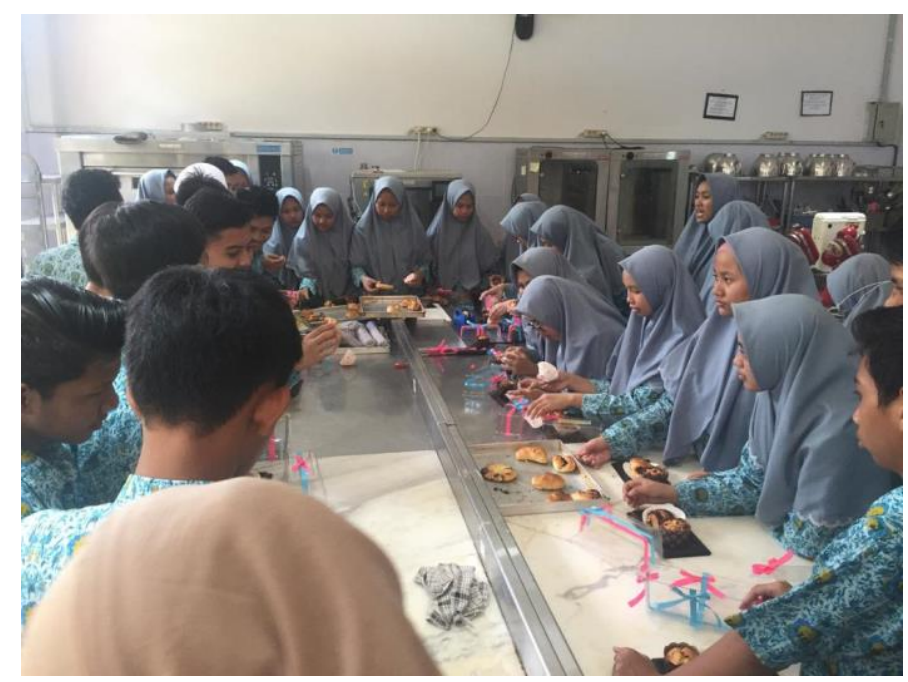

Gambar. 3 Pelatihan pengemasan produk kuliner

Peserta diberikan pelatihan pengemasan dan pemasaran produk kuliner. Peserta melakukan praktik langsung melakukan pengemasan produk kue dan roti yang telah dibuat. Melalui kemasan yang baik, produk roti dan kue akan banyak diminati konsumen.

\section{Simpulan dan rekomendasi}

1. Peserta pelatihan memiliki wawasan ilmu tentang wirausaha kuliner khusunya produk kue dan roti

2. Peserta pelatihan mendapatkan motivasi untuk memulai bisnis kuliner produk kue dan roti

3. Peserta pelatihan mendapatkan ilmu pengemasan dan pemasaran produk kue dan roti. 


\section{Daftar Pustaka}

Kasali, R. (2010). Modul Kewirausahaan. Indonesia, Yayasan Rumah Perubahan.

Anas. F. (2012). Wirausaha Muda dan Kemajuan Ekonomi https://news.okezone.com/read/2012/08/13/58/676816/wirausaha-muda-dankemajuan-ekono mi-bangsa. Diakses online pada tanggal 13 Maret 2018. 